\title{
ANALISIS PRODUKSI LEMPUK DURIAN DI KABUPATEN BENGKALIS (DITINJAU DALAM PERSPEKTIF EKONOMI ISLAM)
}

\author{
Ade Suhartini \\ Sekolah Tinggi Ilmu Ekonomi (STIE) Syariah Bengkalis \\ Email: adesuhartini5@gmail.com
}

\begin{abstract}
ABSTRAK
Produksi adalah kegiatan menghasilkan atau menambah nilai guna barang atau jasa baru sehingga lebih bermanfaat dalam memenuhi kebutuhan.penelitian ini menganalisa 10 usaha dagang yang ada di bengkalis dengan berbagai Masalah yang sering dihadapi dalam usaha lempuk durian adalah stok durian bersifat musiman. Selama ini para petani di Indonesia masih mengandalkan teknologi sederhana dalam mengembangkan produksinya. Hal ini tentu mempengaruhi komoditas panen yang dihasilkan, sehingga persediaan barang juga bersifat musiman (belum stabil). Ketika panen tiba, stok barang melimpah ruah dan harga jualnya bisa anjlok dengan nilai yang sangat rendah. Sedangkan pada saat belum musim, ketersediaan barang menjadi sangat terbatas sehingga harga jualnya bisa melambung tinggi. Pada umumnya produsen lempuk durian mengalami kesulitan untuk memproduksi lempuk durian dalam jumlah besar dengan masa simpan yang cukup panjang. Produk ini tidak tahan lama hingga menunggu musim durian berikutnya, sehingga terjadi kekosongan suplai pada waktu-waktu tertentu. disamping itu, penampilan produk ini masih kurang menarik, terutama dari cata teknik pengemasan yang masih sederhana dan belum dilakukan pelabelan yang mencerminkan nilai gizi, masa kadaluarsa dan jaminan mutu. Pada dasarnya kerusakan yang menyebabkan lempuk durian tidak tahan lama disimpan dalam waktu relatif lama. Penelitian ini bertujuan untuk Untuk menganalisa produksi pada usaha dagang lempuk durian di Kabupaten Bengkalis dan menganalisis kendala-kendala yang dihadapi dalam memproduksi lempuk durian pada usaha dagang di Kabupaten Bengkalis serta menganalisa perspektif ekonomi Islam terhadap produksi lempuk durian di Kabupaten Bengkalis.Penelitian ini merupakan penelitian kualitatif, karena yang menjadi sorotan adalah Produksi Usaha Dagang lempuk durian. teknik pengambilan data dalam penelitian ini adalah sebagai berikut: Observasi, wawancara dan dokumentasi. Hasil penelitian ini menunjukan bahwa produksi lempuk durian ini sangat berpengaruh kepada tenaga kerja, modal, bahan baku dan metode. Kendala-kendala yang dihadapi dalam memproduksi lempuk durian di Kabupaten Bengkalis adalah manajemen, pemasaran dan distribusi. Produksi lempuk durian berdasarkan tinjauan dari perspektif ekonomi islam harus berlandaskan nilai-nilai islam yang berkaitan dengan tenaga kerja, modal, bahan baku dan metode agar durian dapat diolah menjadi lempuk durian yang dapat dikonsumsi oleh konsumen dan mendatangkan manfaat bagi produsen dengan menghasilkan pendapatan dan usaha dapat berjalan dengan sesuai syariah.
\end{abstract}

Kata Kunci: Produksi, Lempuk Durian, Ekonomi Islam. 


\section{PENDAHULUAN}

Pengembangan industri pengolahan pangan di Indonesia yang didukung oleh sumber daya pertanian, baik nabati maupun hewani mampu menghasilkan berbagai produk olahan yang dapat dibuat dari sumber daya lokal maupun daerah. Saat ini dibeberapa negara Asia banyak produk pangan yang diangkat dari jenis pangan lokal dan diolah secara tradisional. Sehingga jumlah dan jenis produk pangan menjadi banyak jumlahnya dan lebih beraneka ragam (Saleh, 2003). Industri pengolahan pangan di Kabupaten Bengkalis sebagian besar termasuk industri pangan berskala kecil meskipun ada sebagian yang berskala besar. Industri-industri pangan berskala kecil pada umumnya masih menggunakan teknologi tradisional, sehingga kualitas produknya masih beragam dan belum sepenuhnya mengikuti standar-standar kualitas yang telah ditetapkan.

Islam menganjurkan agar manusia memanfaatkan potensi dirinya (sumber daya manusia) dalam memanfaatkan sumber daya alam baik didarat maupun dilaut yang tercantum pada firman Allah dalam Al-Quran surah An-Nahl Ayat 14 berikut ini:

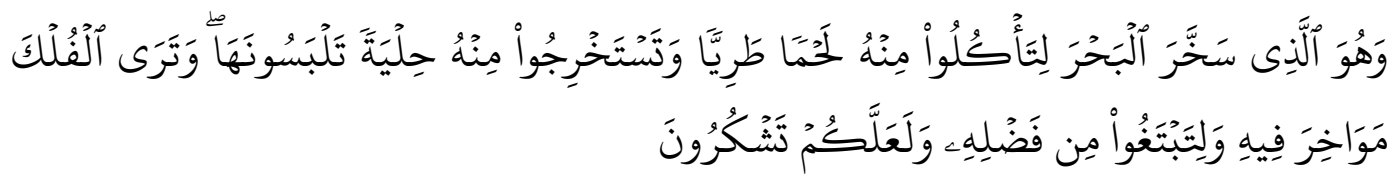

Artinya: "Dan Dia-lah, Allah yang menundukkan lautan (untukmu), agar kamu dapat memakan daripadanya daging yang segar (ikan), dan kamu mengeluarkan dari lautan itu perhiasan yang kamu pakai; dan kamu melihat bahtera berlayar padanya, dan supaya kamu mencari (keuntungan) dari karunia-Nya, dan supaya kamu bersyukur". (QS. An-Nahl (16: 14) (Depag RI 2009, 268)

Segala sumber daya alam ditundukkan Allah untuk diserahkan pengelolaannya kepada manusia. Manusia dituntut untuk dapat mengolah segala apa yang ada di langit dan bumi dengan cara yang baik untuk memenuhi kebutuhan hidup mereka dengan jalan bekerja, salah satunya adalah buah durian Durian dapat diolah menjadi lempuk durian yang dapat dikonsumsi oleh konsumen dan mendatangkan manfaat bagi produsen dengan menghasilkan pendapatan.Pengusaha lempuk durian dapat mencari sumber penghidupan melalui usaha dan bekerja dengan cara mengolah durian menjadi Lempuk Durian.

Pada usaha Lempuk Durian pemasaran yang dipasar dengan bahan baku durian sehingga saat pemasaran laris dipasar namun dikarenakan stok durian bersifat musiman. Selama ini para petani di Indonesia masih mengandalkan teknologi sederhana dalam mengembangkan produksinya. Hal ini tentu mempengaruhi komoditas panen yang dihasilkan, sehingga persediaan barang juga bersifat musiman (belum stabil). Ketika panen tiba, stok barang melimpah ruah dan harga jualnya bisa anjlok dengan nilai yang sangat rendah. Sedangkan pada saat belum musim, ketersediaan barang menjadi sangat terbatas sehingga harga jualnya bisa melambung tinggi. Adapun jumlah rata-rata produksi usaha lempuk durian di kabupaten bengkalis sebagai berikut : 
Tabel 1

Jumlah Produksi Per Tahun Perusahaan Lempuk durian di Kabupaten Bengkalis 2014-2017

\begin{tabular}{|c|l|c|c|c|c|}
\hline \multirow{2}{*}{ No } & \multirow{2}{*}{ Nama Usaha Dagang } & \multicolumn{4}{|c|}{ Jumlah Produksi Per tahun } \\
\cline { 3 - 6 } & & $\begin{array}{c}\mathbf{2 0 1 4} \\
(\mathbf{K g})\end{array}$ & $\begin{array}{c}\mathbf{2 0 1 5} \\
\mathbf{( K g})\end{array}$ & $\begin{array}{c}\mathbf{2 0 1 6} \\
(\mathbf{K g})\end{array}$ & $\begin{array}{c}\mathbf{2 0 1 7} \\
(\mathbf{K g})\end{array}$ \\
\hline 1 & Lempuk Durian Sun No 1 & 3 ton & 4 ton & 4 ton & 4 ton \\
\hline 2 & Citra Rasa & 4.5 ton & 3 ton & 3 ton & 1.5 ton \\
\hline 3 & Yanti & 6 ton & 7 ton & 7 ton & 7 ton \\
\hline 4 & Suziani & 3 ton & 2 ton & 1 ton & 2 ton \\
\hline 5 & Mukhsin & $700 \mathrm{~kg}$ & $600 \mathrm{~kg}$ & - & - \\
\hline 6 & Katimun & $500 \mathrm{~kg}$ & - & - & $400 \mathrm{~kg}$ \\
\hline 7 & Suryani & $500 \mathrm{~kg}$ & $200 \mathrm{~kg}$ & - & - \\
\hline 8 & Durian kampung Rohmad & $300 \mathrm{~kg}$ & $100 \mathrm{~kg}$ & - & \\
\hline 9 & Nurlela & 3 ton & 4 ton & $500 \mathrm{~kg}$ & - \\
\hline 10 & UD Kemas & 2 Ton & 2 Ton & - & - \\
\hline & Jumlah & 23.500 & 22.900 & 15.500 & 14.900 \\
\hline
\end{tabular}

Sumber: Data Olahan Peneliti, Tahun 2017

Melihat data pada tabel diatas diketahui pelaku usaha yang mengembangkan usaha lempuk durian lebih banyak mengalami penurunan dalam produksi lempuk durian, Pada umumnya produsen lempuk durian mengalami kesulitan untuk memproduksi lempuk durian dalam jumlah besar dengan masa simpan yang cukup panjang. Produk ini tidak tahan lama hingga menunggu musim durian berikutnya, sehingga terjadi kekosongan suplai pada waktu-waktu tertentu. Disamping itu, penampilan produk ini masih kurang menarik, terutama dari cata teknik pengemasan yang masih sederhana dan belum dilakukan pelabelan yang mencerminkan nilai gizi, masa kadaluarsa dan jaminan mutu. Pada dasarnya ada dua kerusakan yang menyebabkan lempuk durian tidak tahan lama disimpan dalam waktu relatif lama. Pertama, lempuk durian mudah ditumbuhi oleh yeast, hal ini disebabkan karena permukaan lempuk mempunyai aktivitas air (aw) yang tinggi sekitar 0,55. Kedua, lempuk durian mudah berbau tengik, disebabkan lempuk mengandung lemak sekitar $8 \%$. Sehingga dengan aw dan kadar lemak lempuk durian ini, penetrasi gas oksigen akan memacu terjadinya proses hidrolisis dan oksidasi lemak yang pada akhirnya akan menyebabkan ketengikan.

Di Bengkalis jika saat musim buah durian akan mudah ditemui penjual durian. Ketersediaan produk yang kurang stabil seperti ini menjadi salah satu kendala besar bagi para pelaku usaha, sehingga mereka belum bisa memenuhi permintaan. Selain dikarenakan stok barang yang bersifat musiman hal yang penting terbatasnya modal., tapi berbeda dengan usaha yang sedang akan dirintis, meminjam uang di bank akan menjadi jalan yang sangat-sangat sulit. disini permasalahannya hanya satu, anda mau bertindak atau tidak. Kendala dalam usaha Lempuk Durian selanjutnya berkaitan dengan proses produksi dan menjual produk. 


\section{TELAAH PUSTAKA}

\section{Produksi}

Produksi dapat didefinisikan sebagai dari hasil suatu proses atau aktivitas ekonomi dengan memanfaatkan beberapa masukan (input). Dengan demikian, kegiatan produksi tersebut adalah pengkombinasian berbagai input untuk menghasilkan output (Agung et. al. 2008). Istilah produksi dan operasi sering digunakan dalam suatu organisasi yang menghasilkan keluaran atau output, baik yang berupa barang maupun jasa. Secara umum produksi diartikan sebagai suatu kegiatan atau proses yang mentransformasikan masukan (input) menjadi hasil keluaran (output) (Assauri 2004).

Proses produksi adalah cara atau metode untuk menciptakan atau menambah guna suatu barang atau jasa dengan memanfaatkan sumber yang ada. Proses produksi merupakan ketrkaitan komponen satu (input) dan komponen lain (output) dan juga menyangkut proses interaksi satu dengan lainnya untuk mencapai satu tujuan (Machfoedz 2007).

Fungsi produksi merupakan suatu skedul (atau tabel atau persamaan matematis) yang menggambarkan jumlah output maksimum yang dapat dihasilkan dari suatu faktor produksi tertentu pula, atau singkatnya fungsi produksi adalah katalog dari kemungkinan hasil produksi (Ari, 2004).

Proses produksi dapat didefinisikan sebagai suatu kegiatan yang melibatkan tenaga manusia, bahan, serta peralatan untuk menghasilkan produk yang berguna (Yazid 2005). Proses produksi atau proses operasi adalah proses perubahan masukan menjadi keluaran (Pangestu 2000). Proses produksi adalah proses transformasi input menjadi output, atau dengan kata lain sebuah proses mengubah input menjadi output (Sule 2008).

Kegiatan produksi erat kaitannya dengan faktor-faktor produksi, sehingga bagi seorang pimpinan sebagai pengambil keputusan harus diperhatikan hal ini dengan serius, dimana faktor-faktor inilah nantinya yang diolah dalam suatu proses untuk menambah kegunaan suatu barang atau jasa. Adapun faktor-faktor produksi tersebut adalah tenaga kerja, modal, skill, bahan baku serta peralatan dan mesin (Assauri 2004, 4). Jalan kegiatan produksi tergantung dari tersedianya faktor produksi. Faktor produksi adalah segala sesuatu yang perlukan dalam kegiatan produksi terhadap suatu barang dan jasa. Faktor-faktor produksi terdiri dari alam (natural resources), tenaga kerja (labor), modal (capital), dan keahlian (skill) atau sumber daya pengusaha (enterpreneurship).

Adapun faktor-faktor yang perlu dipertimbangkan dalam penyusunan perencanaan produksi atau yang sering disebut dengan 4M (Pangestu 2000a, 6) adalah:

1. Sumber daya alam

2. Modal

3. Bahan baku

4. Metode

Kegiatan produksi tentunya memerlukan unsur-unsur yang dapat digunakan dalam proses produksi yang disebut faktor produksi. Faktor produksi yang bisa digunakan dalam proses produksi terdiri atas sumber daya alam, tenaga kerja manusia, modal dan kewirausahaan.

Proses produksi adalah tahap-tahap yang harus dilewati dalam memproduksi 
barang atau jasa. Ada proses produksi membutuhkan waktu yang lama, misalnya dalam pembuatan gedung pencakar langit, pembuatan pesawat terbang, dan pembuatan kapal serta lain-lainnya

Salah satu fungsi terpenting dalam usaha mencapai tujuan perusahaan pabrik adalah perencanaan dan pengawasan produksi. Biasanya kegiatan perencanaan dan pengawasan produksi disuatu perusahaan pabrik dilakukan oleh bagian perencanaan pengawasan produksi.

Tujuan dari produksi antara lain sebagai berikut:

1. Menghasilkan barang atau jasa

2. Meningkatkan nilai guna barang atau jasa

3. Meningkatkan kemakmuran masyarakat

4. Meningkatkan keuntungan

5. Meningkatkan lapangan usaha

6. Menjaga kesinambungan usaha perusahaan

Cara meningkatkan jumlah dan mutu produksi sebagai berikut (Syafril 2004, 87):

1. Intensifikasi adalah sebuah usaha untuk meningkatkan mutu (kualitas) dan jumlah (kuantitas) hasil produksi dengan cara meningkatkan produktivitas dan cara kerja. Meningkatkan kualitas kerja, Memperbaiki cara berproduksi, Peningkatan jam operasi mesin, Menerapkan panca usaha tani dalam bidang pertanian.Contoh Intensifikasi adalah seorang petani padi yang ingin meningkatkan hasil produksi padinya tanpa menambah faktor produksi (dalam hal ini lahan sawah). Yakni dengan cara menerapkan Panca Usaha Tani yang terdiri dari : menggunakan bibit unggul, pemupukan yang tepat, pengendalian hama yang baik, pengolahan tanah yang baik, dan irigasi yang bagus. Sehingga hasil panen padi meningkat meskipun luas sawah tetap.

2. Ekstentifikasi adalah sebuah usaha untuk meningkatkan mutu (kualitas) dan jumlah (kuantitas) hasil produksi dengan cara menambah faktor produksi. Contoh Ekstensifikasi adalah seorang petani padi yang berusaha meningkatkan hasil produksi padinya dengan cara menambah luas sawah. Sehingga hasil produksi padi meningkat.

3. Diversifikasi adalah usaha untuk meningkatkan produksi dengan cara menambah jenis atau keanekaragaman hasil produksi. Berikut beberapa contoh usaha meningkatkan hasil produksi dengan cara diversifikasi, Selain menghasilkan kain juga memproduksi pakaian jadi, Selain memproduksi televisi dibuat pulaantena televisi, radio, dan amplifer, Selain menanam padi, pada lahan yang masih kosong ditanami juga palawija.

4. Dengan cara meningkatkan penguasaan ilmu pengetahuan dan teknologi.Berikut beberapa contoh usaha meningkatkan mutu dan hasil produksi dengan cara rasionalisasi, Untuk menghemat tenagakerja dan efektivitas produksi, maka digunakan tenaga kerja mesin, Melaksanakan kegiatan produksi dengan menerapkan manajemen yang baik.

\section{Produksi dalam Islam}

Konsep produksi yang sesuai dengan nilai Islam adalah konsep teknologi konstan, dalam arti bahwa teknologi yang digunakan adalah teknologi yang memanfaatkan sumber daya manusia sedemikian rupa sehingga manusia-manusia tersebut mampu meningkatkan harkat kemanusiaannya (Syafril 2004, 87). 
Pentingnya peranan produksi dalam memakmurkan kehidupan suatu ba ngsa dan taraf hidup manusia, disebutkan dalam beberapa ayat dan hadits, seperti: Surat Al-Qashash ayat 73:

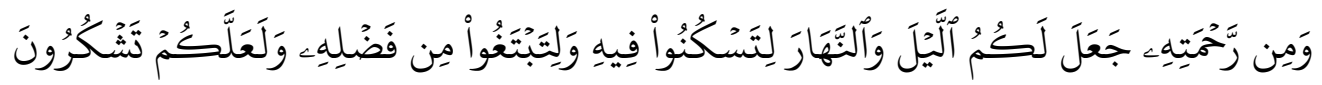

Artinya: "Dan karena rahmat-Nya, Dia jadikan untukmu malam dan siang, supaya kamu beristirahat pada malam itu dan supaya kamu mencari sebahagian dari karunia-Nya (pada siang hari) dan agar kamu bersyukur kepada-Nya". (Depag RI 1997, 395)

Surat Ar- Rum ayat 23:

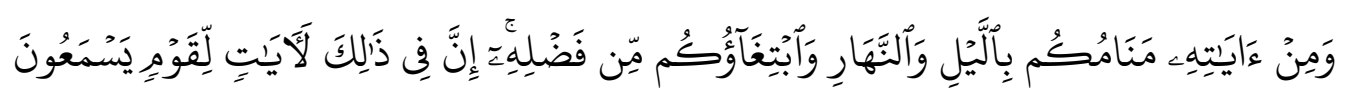

Artinya: "Dan di antara tanda-tanda kekuasaan-Nya ialah tidurmu di waktu malam dan siang hari dan usahamu mencari sebagian dari karuniaNya. Sesungguhnya pada yang demikian itu benar-benar terdapat tanda-tanda bagi kaum yang mendengarkan. (Depag RI 1997, 407)

Apabila dikaji secara terperinci dalam Al-Qur'an, maka kita akan mendapatkan bahwa penekanan atas usaha manusia untuk memperoleh sumber penghidupan merupakan salah satu prinsip ekonomi yang mendasar di dalam Islam. Bagi Islam, memproduksi sesuatu bukanlah sekedar untuk dikonsumsi sendiri atau dijual ke pasar. Dua motivasi itu belum cukup karena masih terbatas pada fungsi ekonomi. Islam menekankan bahwa setiap kegiatan produksi harus pula mewujudkan fungsi sosial.

Tujuan dari kegiatan produksis dua hal pokok pada tingkat pribadi muslim dan umat Islam adalah sebagai berikut (Syafril 2004, 78):

1. Memenuhi kebutuhan setiap individu. Di dalam ekonomi Islam kegiatan produksi menjadi sesuatu yang unik dan istimewa sebab di dalamnya terdapat faktor itqan (profesionalitas) yang dicintai Allah dan ihsan yang diwajibkan Allah atas segala sesuatu. Pada tingkat pribadi muslim, tujuannya adalah merealisasi pemenuhan kebutuhan baginya.

2. Merealisasikan kemandirian umat, hendaknya umat memiliki berbagai kemampuan, keahlian dan prasarana yang memungkinkan terpenuhinya kebutuhan material dan spiritual.

Pada prinsipnya kegiatan produksi terkait seluruhnya dengan syariat Islam, dimana seluruh kegiatan produksi harus sejalan dengan tujuan dari konsumsi itu sendiri. Konsumsi seorang muslim dilakukan untuk mencari falah (kebahagiaan), demikian pula produksi dilakukan untuk menyediakan barang dan jasa guna falah tersebut.

Prinsip dasar ekonomi Islam adalah keyakinan kepada Allah SWT sebagai Rabb dari alam semesta. Ikrar akan keyakinan ini menjadi pembuka kitab suci umat Islam (QS. Al-Jaatsiyah: 13).

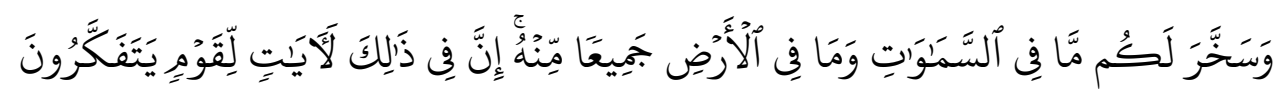

Artinya: "Dan dia Telah menundukkan untukmu apa yang di langit dan apa yang di bumi semuanya, (sebagai rahmat) daripada-Nya. Sesungguhnya pada yang 
demikian itu benar-benar terdapat tanda-tanda (kekuasaan Allah) bagi kaum yang berfikir". (Depag RI 1997, 500)

Konsep produksi di dalam ekonomi Islam tidak semata-mata bermotif maksimalisasi keuntungan dunia, tetapi lebih penting untuk mencapai maksimalisasi keuntungan akhirat. Ayat 77 surat Al-Qashas mengingatkan manusia untuk mencari kesejahteraan akhirat tanpa melupakan urusan dunia. Artinya, urusan dunia merupakan sarana untuk memperoleh kesejahteraan akhirat. Orang bisa berkompetisi dalam kebaikan untuk urusab dunia, tetapi sejatinya mereka sedang berlomba-lomba mencapai kebaikan di akhirat.

\section{METODOLOGI PENELITIAN}

\section{Lokasi dan Waktu Penelitian}

Lokasi dan Adapun tempat penelitian yang akan dilakukan adalah di Kabupaten Bengkalis mengambil data dari pelaku usaha lempuk durian yang ada di kabupaten bengkalis, penelitian ini dilaksanakan pada usaha lempuk durian antara lain Usaha Dagang Lempuk Durian Sun No 1, Usaha Dagang Lempuk Durian Citra Rasa, Usaha Lempuk Durian Yanti, Usaha Lempuk Durian Suziani, Usaha Lempuk Durian Mukhsin, Usaha Lempuk Durian Katimun,Usaha Dagang Lempuk Durian Suryani, Usaha Dagang Lempk Durian Kampong Rohmad,Usaha Dagang Lempuk Durian Nurlela dan Usaha Lempuk Durian UD Kemas. Pemilihan lokasi berdasarkan pertimbangan produksi lempuk durian cukup terkenal dibandingkan daerah lainnya. Penelitian ini dilakukan mulai Bulan September Tahun 2017 sampai dengan Bulan Februari Tahun 2018.

\section{Jenis dan Sumber Data}

Jenis data dalam penelitian ini adalah berupa data deskriptif kuantitatif yakni data yang menggambarkan dalam bentuk uraian dari kejadian yang sesungguhnya, melalui tanggapan responden terhadap permasalahan yang diajukan, dengan menggunakan angka-angka statistik. Adapun jenis dan sumber data yang akan diambil dalam pelaksanaan penelitian ini adalah sebagai berikut:

1. Data primer

Data Primer yaitu data yang diperoleh dari hasil penelitian lapangan dengan cara melakukan observasi dan wawancara langsung dengan narasumber yang berkaitan dengan permasalahan yang diteliti dengan mengajukan pertanyaanpertanyaan terhadap informan tentang Analisis Produksi Lempuk durian di Kabupaten Bengkalis ditinjau dalam Perspektif Ekonomi Islam.

2. Data Sekunder

Data Sekunder yaitu merupakan data-data yang diperoleh atau dikumpulkan oleh penelitian dari sumber yang ada. Data sekunder dalam penelitian ini adalah berbagai laporan penelitian, jurnal dan buku-buku yang berkaitan dengan Analisis Produksi Lempuk durian di Kabupaten Bengkalis ditinjau dalam Perspektif Ekonomi Islam. Data sekunder data yang diperoleh dari studi kepustakaan maupun teknis dokumentasi dengan memanfaatkan sumbersumber yang dapat menunjang aspek yang diteliti berupa:

a. Profil Kabupaten Bengkalis.

b. Data Pelaku Usaha Lempuk durian di Kabupaten Bengkalis. 


\section{Teknik Analisa Data}

Analisis data yang dilakukan sejalan dengan pelaksanaan penelitian di lapangan.data yang diperoleh setiap kali melaksanakan peneltian dianalisis untuk dapat mengetahui maknanya. Data hasil wawancara dan studi dokumentasi terlebih dahulu dianalisis sebelum dijadikan acuan dalam penelitian. Hasil analisis ini sangat bermanfaat terutama dalam menentukan rencana penelitian sebelumnya analisis data adalah proses mencari dan menyusun secara sistematis data yang diperoleh dari hasil wawancara, catatan lapangan, dan dokumentasi , dengan cara mengorganisasikan data kedalam unit-unit, melakukan sintesa,menyusun kedalam pola, memilih mana yang penting dan akan dipelajari dan membuat kesimpulan sehingga mudah dipahami oleh diri sendiri dan orang lain.Sesuai dengan metode pendekatan yang digunakan, maka dalam penelitian inianalisis yang digunakan sebagai berikut:

1. Tahap Pertama, mendasar dalam pendekatan doktrinal, analisis digunakan dengan analisis kualitatif. Dalam tahap ini terutama akan diadakan inventarisasi terhadap beberapa norma hukum yang terkait dengan zakat dan pengelolaan zakat pada khusunya. Dalam hal ini akan dikumpulkan terhadap semua asas-asas dan kaidah-kaidah yang terkait dengan permasalahannya, untuk kemudian di organisir ke dalam suatu system yang komprehensif.

2. Tahap Kedua, yang mendasar pada pendekatan non-doktrinal, analisakan dilakukan dengan menggunakan metode analisa kualitatif, yang dilakukan melalui tahapan-tahapan sebagai berikut:

a. Data hasil pengamatan dengan data hasil wawancara,

b. Membandingkan apa yang dikatakan orangdi depan umum, dengan apa yang dikatakan secara pribadi,

c. Membandingkan apa yang dikatakan responden pada situasi penelitian dengan apa yang dikatakannya sepanjang waktu,

d. Membandingkan keadaan dan perspektif seorang dengan berbagai pendapat dan pandangan orangyang berkaitan.

e. Membandingkan hasil wawancara dengan isi suatu dokumen yang berkaitan.Pertama, dilakukan pemprosesan dan penyusunan data dalam satuan-satuan tertentu, setelah sebelumnya dilakukan display data dan reduksi data.

f. Teknik analisis yang digunakan adalah analisis kualitatif dengan munggunakan pola pikir induktif.

Teknik ini dilaksanakan dengan metode interaktif sebagaimana dikemukakan oleh Mattew B. Milles dan A.Machael Hubermen, yang terdiri dari tiga jenis kegiatan, yaitu reduksidata, pengajian data dan penarikan kesimpulan, yang dapat dilakukanpada saat, sebelum dan selama pengumpulan data.Reduksi data diartikan sebagai proses pemilihan, pemusatan perhatian pada penyederhanaan, pengabstrakan dan transformasi data "kasar" yang muncul dari catatan tertulis di lapangan. Penyajian data dalam suatu"penyajian" sekumpulan informasi tersusun yang memberi kemungkinan adanya penarikan kesimpulan dan pengambilan tindakan. (Miles dan Hubermen 1992, 16-18) 


\section{HASIL DAN PEMBAHASAN}

\section{Produksi Pada Usaha Lempuk Durian di Kabupaten Bengkalis.}

Proses Lempuk Durian harus dipandang sebagai suatu siklus yang berupaya secara terus menerus atau berkesinambungan mencapai tujuan yang diharapkan. Siklus proses produksi dimulai dari riset pasar untuk mengetahui kebutuhan konsumen selanjutnya dari riset pasar untuk mengetahui kebutuhan kinsumen, selanjutnya dari riset pasar diperlukan perencanaan proses produksi,dapat berjalan sehingga diperlukan mesin-mesin dan peralatan yang dibutuhkan untuk mengolah durian menjadi lempuk durian agar proses produksi dapat berjalan dengan baik dan lancer, kebutuhan peralatan dalam pengolahan serta bahan bakar membawa konsekuensi pada perencanaan metode kerja selanjutnya pengemasan selanjutnya pemasaran dan penyimpanan lempuk durian serta pendistribusian lempuk durian kepada konsumen.

Sedangkan produksi secara islam lebih menekankan berproduksi demi untuk memenuhi kebutuhan orang banyak, bukan hanya sekadar memenuhi segelintir orang yang memiliki uang, sehingga memiliki dayabeli yang lebih baik. Karena itu bagi islam produksi yang berkembang baik secara kuantitatif maupun kualitatif tidak dengan sendirnya mengindikasi kesejahteraan bagi masyarakat. Menjadi produkstif adalah tuntunan bagi setiap manusia adapun agama mengajarkan agar umatnya dapat memanfaatkan waktu sebaik mungkin demi menghasilkan sesuatu yang bearti baik berhubungan secara langsung dengan Allah SWT (hablum minnallah) maupun hubungan langsung antar manusia (hablum minas). Agama islam selalu menekankan pada umatnya untuk selalu berusaha agar menjadi lebih baik, firman Allah QS: Ar Ra'd: 11:

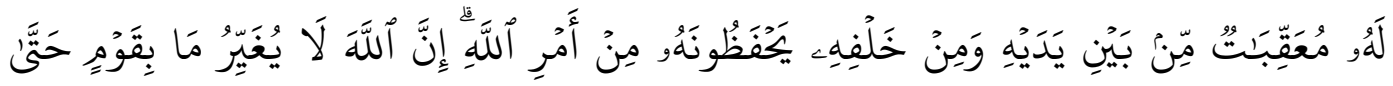

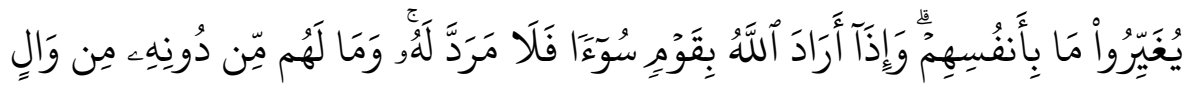

Artinya: "Bagi manusia ada malaikat-malaikat yang selalu mengikutinya bergiliran, di muka dan di belakangnya, mereka menjaganya atas perintah Allah. esungguhnya Allah tidak merobah Keadaan sesuatu kaum sehingga mereka merobah keadaan yang ada pada diri mereka sendiri. dan apabila Allah menghendaki keburukan terhadap sesuatu kaum, Maka tak ada yang dapat menolaknya; dan sekali-kali tak ada pelindung bagi mereka selain Dia”."

Dari ayat diatas dapat diketahui bahwa kehidupan manusia tidak akan berubah jika dia tidak berusaha untuk merubah nasib dan takdirnya islam pun sesungguhnya menerima motif-motif berproduksi seperti pola pikir ekonomi konvesional hanya bedanya islam juga menjelaskan nilai-nilai moral disamping utilitas ekonomi.bahkan sebelum itu islam menjelaskan mengapa produksi harus dilakukan menurut ajaran islam manusia adalah khalifatullah atau wakil allah dimuka bumi dan berkewajiban untuk memakmurkan bumi dengan jalan beribadah kepadanya untuk mengetahui beberapa baiaya produksi yang dikeluarkan tiap-tiap perusahan lempuk durian pada tabel 2 dibawah ini: 
Tabel 2

Produksi Industri Lempuk Durian di Kabupaten Bengkalis Tahun 2017

\begin{tabular}{|c|l|c|c|c|c|c|c|}
\hline \multirow{2}{*}{ No } & \multirow{2}{*}{$\begin{array}{c}\text { Nama } \\
\text { Perusahaan }\end{array}$} & Produksi & $\begin{array}{c}\text { Bahan Baku } \\
\text { (durian) }\end{array}$ & Gula & $\begin{array}{c}\text { Tenaga } \\
\text { Kerja }\end{array}$ & $\begin{array}{c}\text { Mesin/ } \\
\text { Peralatan }\end{array}$ & Metode \\
\cline { 3 - 8 } & $\begin{array}{l}\text { Lempuk Durian } \\
\text { Sun No 1 }\end{array}$ & $3.833 \mathrm{~kg}$ & $4000 \mathrm{~kg}$ & $1000 \mathrm{~kg}$ & 3.795 .000 & 5.000 .000 & 24.095 .000 \\
\hline 2 & Citra Rasa & $1.437 \mathrm{~kg}$ & $1.500 \mathrm{~kg}$ & $375 \mathrm{~kg}$ & 2.000 .000 & 3.000 .000 & 15.000 .000 \\
\hline 3 & Yanti & $6.708 \mathrm{~kg}$ & $7.000 \mathrm{~kg}$ & $1750 \mathrm{~kg}$ & 3.500 .000 & 5.000 .000 & 30.000 .000 \\
\hline 4 & Suziani & $1.916 \mathrm{~kg}$ & $2.000 \mathrm{~kg}$ & $500 \mathrm{~kg}$ & 3.600 .000 & 6.000 .000 & 24.900 .000 \\
\hline 5 & Mukhsin & - & - & & - & - & - \\
\hline 6 & Katimun & $384 \mathrm{~kg}$ & $400 \mathrm{~kg}$ & $100 \mathrm{~kg}$ & 1.000 .000 & 2.000 .000 & 3.005 .900 \\
\hline 7 & Suryani & - & - & - & - & - & - \\
\hline 8 & Rohmad & - & - & - & - & - & - \\
\hline 9 & Nurlela & - & - & - & - & - & - \\
\hline 10 & UD Kemas & - & - & - & - & - & - \\
\hline
\end{tabular}

Sumber : Pemilik perusahaan lempuk durian Kabupaten Bengkalis, tahun 2017

Dilihat dari tabel diatas diketahui untuk menghasilkan lempuk durian perkiraan dengan rasio antara bahan baku durian dan lempuk yang dihasilkan yaitu 24:25 atau setiap $\mathrm{kg}$ lempuk diperlukan 1,04 $\mathrm{kg}$ durian sedangkan untuk penggunaan gula pasir rasio perbandingannya adalah 24:6 artinya untuk menghasilkan $1 \mathrm{~kg}$ lempuk dibutuhkan gula sebesar $0,25 \mathrm{~kg}$ gula pasir.

1. Tenaga kerja (Man)

Tenaga kerja lempuk durian adalah tenaga kerja yang menangani proses pengolahan secara langsung. Tenaga kerja ini terbagi atas tenaga kerja tetap dan tenaga kerja tidak tetap (borongan). Usaha lempuk durian merupakan industri rumah tangga yang memanfaatkan tenaga kerja lokal dan juga menampung hasil kebun atau petani durian setempat. Jumlah tenaga kerja yang di gunakan tergantung dari banyaknya lempuk yang ingin dihasilkan. Jumlah tenaga kerja pada usaha lempuk durian dari tahun 2014-2017 dapat dilihat pada tabel 3 berikut ini:

Tabel 3

Jumlah Tenaga Kerja Bagian Produksi Usaha Lempuk dari Tahun 2014-2017

\begin{tabular}{|c|l|c|l|}
\hline No & Nama Usaha Dagang & $\begin{array}{c}\text { Jumlah } \\
\text { Tenaga kerja } \\
\text { (orang) }\end{array}$ & Keterangan \\
\hline 1 & Lempuk Durian Sun No 1 & 8 & Tenaga kerja tetap dan tidak tetap \\
\hline 2 & Citra Rasa & 6 & Tenaga kerja tidak tetap \\
\hline 3 & Yanti & 10 & Tenaga kerja tetap \\
\hline 4 & Suziani & 6 & Tenaga kerja tetap dan tidak tetap \\
\hline 5 & Mukhsin & - & - \\
\hline 6 & Katimun & 4 & Tenaga kerja tidak tetap \\
\hline 7 & Suryani & - & - \\
\hline 8 & Durian Kampung Rohmad & - & - \\
\hline
\end{tabular}




\begin{tabular}{|c|l|c|c|}
\hline 9 & Nurlela & - & - \\
\hline 10 & UD Kemas & - & - \\
\hline & Total & 34 & - \\
\hline
\end{tabular}

Sumber : Data Primer Di Olah Peneliti, 2017

Dari tabel diatas terlihat bahwa jumlah tenaga kerja lempuk durian sun no 1 memiliki tenaga kerja 8 orang dengan status tenaga kerja tetap dan tidak tetap, untuk usaha dagang citra rasa memiliki tenaga kerja 6 orang yang berstatus tenaga kerja tidak tetap,dan usaha dagang yanti memiliki karyawan sebanyak 10 orang dengan status tenaga kerja tetap serta usaha dagang yanti yang paling banyak memiliki karyawan itu dikarenakan produk usaha produksi lempuk durian yang ada lebih banyak dibandingkan usaha dagang yang ada di kabupaten bengkalis.dan pada usaha dagang suziani memiliki karyawan 6 orang dengan status tenaga kerja tidak tetap. Serta usaha dagang katimun memiliki karyawan hanya 4 orang dengan status tenaga kerja tidak tetap karena produksi lempuk durian yang sedikit dibandingkan dengan usaha dagang lempuk durian yang lain.

\section{Modal}

Dalam pelaksanaan proses produksi, keberadaan mesin sebagai alat bantu untuk menjalankan proses produksi sangat dibutuhkan. Dengan adanya mesin akan dapat membantu kelancaran proses produksi. Penggunaan mesin dalam suatu proses produksi bermula dari waktu manusia yang tidak hanya memperoduksi hanya memenuhi kebutuhan sendiri, akan tetapi untuk memenuhi kebutuhan orang lain. Keadaan ini mengharuskan manusia memperoduksi suatu produk dalam jumlah yang banyak, maka untuk memenuhi tuntutan yang demikian, hampir semua jenis produk memerlukan bantuan mesin agar dapat mengolahnya sehingga dapat menghasilkan produk yang diinginkan serta sesuai dengan standar yang telah ditetapkan.

\section{Bahan Baku (Material)}

Bahan baku adalah bahan utama/bahan pokok dan merupakan komponen utama dari suatu produk. Bahan baku merupakan faktor yang sangat penting dalam industri. Sebagai faktor utama dalam industri bahan baku penentu kelancaran dari pada kegiatan produksi. Maka dari itu, perusahaan harus dapat menjaga ketersediaan bahan baku didalam perusahaan agar perusahaan tidak kekurangan bahan baku. Namun, ketika bahan baku menjadi masalah dalam industri, dimana terjadi kelangkaan bahan baku (sulitnya memperoleh bahan baku), harga bahan baku yang cendrung mahal dan atau karena faktor lainnya maka kegiatan dalam perusahaan terhenti atau tidak dapat berjalan lancar.

\section{Metode (Method)}

Metode ini juga dapat diartikan suatu keahlian dalam memproduksi suatu usaha. Produksi Keahlian adalah keahlian atau keterampilan individu mengkoordinasikan dan mengelola faktor produksi untuk menghasilkan barang dan jasa. Serta diperlukan juga Faktor kewirausahaan adalah keahlian atau keterampilan yang digunakan seseorang dalam mengkoordinir faktor-faktor produksi untuk menghasilkan barang dan jasa. Sebanyak dan sebagus apa pun faktor produksi alam, tenaga manusia, serta modal yang dipergunakan dalam 
proses produksi, jika dikelola dengan tidak baik, hasilnya tidak akan maksimal.

Peran pemerintah daerah sangat diperlukan untuk menunjang keberhasilan dari usaha kecil menengah (UKM) ini. Oleh karena itu, Pemerintah Daerah harus lebih sering melakukan sosialisasi serta pelatihan bagi pelaku usaha kecil menengah ini agar keahlian mereka bisa lebih meningkat lagi pembinaan dan pelatihan juga diberikan kepada beberapa pengusaha lempuk durian oleh Dinas Perindustrian dan Perdagangan Kabupaten Bengkalis dalam rangka pembinaan dan pengembangan industri lempuk durian.

\section{Kendala-Kendala yang Dihadapi dalam Memproduksi Lempuk durian di Kabupaten Bengkalis}

Berdasarkan penelitian dan analisis penulis, maka penulis menemukan kendala-kendala yang dihadapi dalam memproduksi lempuk durian di Kabupaten Bengkalis, berikut adalah kendala-kendala yang dihadapi dalam memproduksi lempuk durian di Bengkalis adalah sebagai berikut:

1. Manajemen

Manajemen merupakan pihak yang merapkan fungsi-fungsi lain yang meliputi: perencanaan, pengorganisasian, pemotifasian, pengendalian yang dilaksanakan untuk mencapai tujuan yang telah ditentukan. Namun untuk tahap proses manajemen harus merencanakan aktivitas industri lempuk durian lebih terkoordinir karena pada saat ini industri lempuk durian di kabupaten bengkalis belum memiliki perencanaan tertulis untuk jangka panjang, menengah maupun jangka pendek. Hal ini terlihat dari tidak adanya visi, misi dan tujuan yang dirumuskan secara jelas dan spesifik. Industri ini juga masih dalam bentuk industri kekeluargaan sehingga pelimpahan wewenang masih terenstralisasi pada sumber daya pemilik sebagai pemimpin uisaha.pati langsung oleh pemilik, posisi ini berwenang dalam mengambil keputusan perencanaan produksi,produksi dan hasil produksi.

\section{Pemasaran}

Dalam memasarkan lempuk durian, hanya beberapa industri saja yang telah melakukan promosi secara langsung, itu pun terjadi pada saat pameran pembangunan yang di fasilitasi oleh pemerintah daerah. Sedangkan pengusaha lain hanya berupaya membangun citra baik kepada para distributor dan konsumen. Disamping itu kedekatan industri lempuk durian dengan pelanggan dan konsumen diharapkan dapat membantu perusahaan dalam mempromosikan produknya.

\section{Distribusi}

Saluran Distribusi yang bahan baku pada saat ini tidak musim panen durian di Kabupaten Bengkalis yang cukup panjang, merupakan kelemahan bagi industri untuk bisa mengembangkan usahanya. disamping itu saluran distribusi lempuk durian yang beragam dan tidak semua pengusaha memiliki saluran distribusi yang efektif.

Sasaran utama bagi pemasaran lempuk durian adalah para konsumen domestik seperti dari Kabupaten Bengkalis sendiri, Kota Dumai, Kota Pekanbaru, Kabupaten Siak dan sebagainya tetapi tidak menutup kemungkinan bagi konsumen luar negeri yang berkunjung ke kabupaten bengkalis seperti dari Malaysia dan Singapura. 


\section{Perspektif Ekonomi Islam Terhadap Produksi Lempuk Durian di Kabupaten Bengkalis}

Permasalahan ekonomi munculnya dikarenakan sumber bahan baku untuk memenuhi kebutuhan produksi tidak tercukupi tetapi juga biasa disebabkan adanya pengabaian optimalisasi segala anugerah allah, baik dalam bentuk sumber daya alam maupun manusia. Sikap tersebut dalam al-quran sering disebut sebgai kezhaliman dan pengingkaran terhadap nikmat allah, hal itu tercantum dalam surah Ibrahim 32-34:

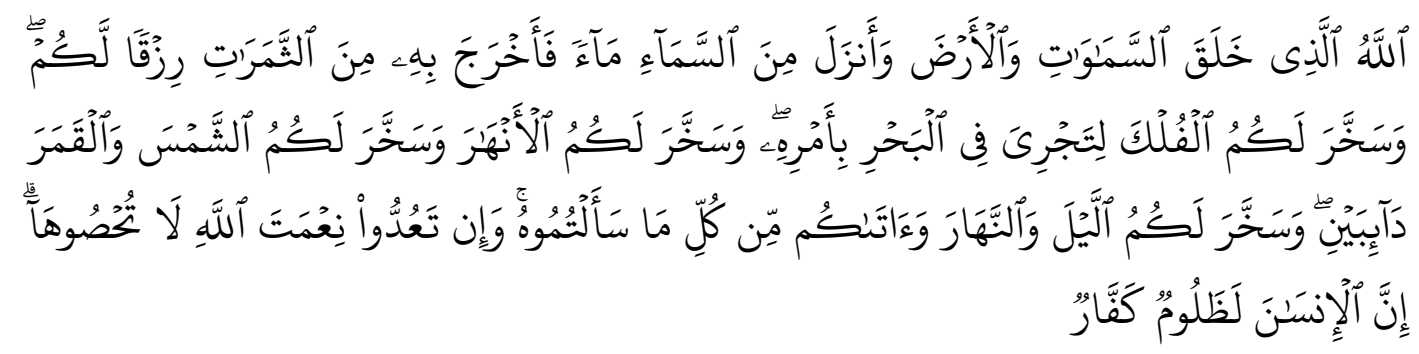

Artinya: 32. Allah-lah yang telah menciptakan langit dan bumi dan menurunkan air hujan dari langit, kemudian Dia mengeluarkan dengan air hujan itu berbagai buah-buahan menjadi rezki untukmu; dan Dia telah menundukkan bahtera bagimu supaya bahtera itu, berlayar di lautan dengan kehendak-Nya, dan Dia telah menundukkan (pula) bagimu sungai-sungai. 33. dan Dia telah menundukkan (pula) bagimu matahari dan bulan yang terus menerus beredar (dalam orbitnya); dan telah menundukkan bagimu malam dan siang. 34. dan Dia telah memberikan kepadamu (keperluanmu) dan segala apa yang kamu mohonkan kepadanya. dan jika kamu menghitung nikmat Allah, tidaklah dapat kamu menghinggakannya. Sesungguhnya manusia itu, sangat zalim dan sangat mengingkari (nikmat Allah).

Hal ini membawa implikasi bahwa produksi bukan sekadar efesiensi tetapi secara luas adalah sebagaimana mengoptimalisasi pemanfaatan sumber daya ekonomi dalam perspektif islam bersifat ulturistik sehingga produsen tidak hanya menegrjakan keuntungan maksimum saja. Produsen harus mengejar tujuan yang lebih luas sebagaimana tujuan akhirat. Kegiatan produksi juga harus berpedoman kepada nilai-nilai keadilan dan kebajikan bagi masyarakat.

Adapun hal yang baik untuk dinikmati adalah hasil dari usaha sendiri, karena itu lebih baik daripada meminta kepada orang lain.Usaha lempuk durian merupakansalah satu penunjang perekonomian keluarga di Kabupaten Bengkalis. Disamping itu, usaha lempuk durianjuga berperan untuk membentuk masyarakat menjadi manusia produktif karenabisa memanfaatkan waktu yang dimilikinya untuk meningkatkan produktifitas dan dapat menyerap tenaga kerja, sehingga pengangguran pun berkurang dan perekonomian keluarga pun semakin meningkat.

Ayat Al-Qur'an yang menjelaskan tentang sikap jujur dalam memasarkanhasil produksi terdapat dalam QS. Al-Muthaffifin ayat 1-6:

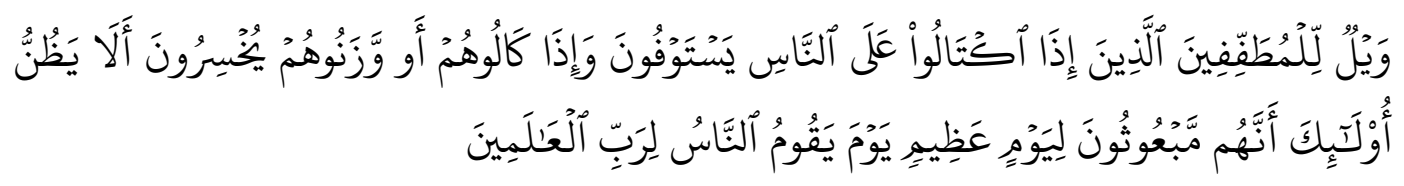

Artinya: "Kecelakaan besarlah bagi orang-orang yang curang, (yaitu) orangorang yang apabila menerima takaran dari orang lain mereka minta dipenuhi, 
dan apabila mereka menakar atau menimbang untuk orang lain, mereka mengurangi. Tidakkah mereka itu mengira, bahwa sesungguhnya mereka akan dibangkitkan, pada suatu hari yang besar, yaitu pada hari (ketika) semua orang bangkit menghadap Tuhan seluruh alam".

Dari ayat di atas dapat kita ketahui bahwa Islam menganjurkan sikap jujur dan tidak boleh curang dalam memasarkan hasil produksi dan tidak merugikan orang lain, baik dalam harga, produk, maupun takaran dan timbangan. Dilihat dari segi usaha mikro lempuk durian yang berada di Kabupaten Bengkalis telah sesuai dengan prinsip-prinsip ekonomi Islam tanpa adanya penipuan dalam jual beli, segi produk, pemasaran sertamakanan yang disajikan halal. Usaha lempuk durian ini telah mendapatkan sertifikasi dari Majelis Ulama Indonesia (MUI) walaupun masih ada yang belum mendaftarkan ke Majelis Ulama Indonesia (MUI) untuk mendapatkan sertifikat halal dari Dinas Kesehatan dan BPOM telah mensertifikasi produk yang diproduksinya.

\section{KESIMPULAN DAN SARAN}

Dari hasil pembahasan dan analisis pada bab-bab sebelumnya, maka dapat disimpulkan bebarapa poin penting yang berkaitan dengan analisis produksi usaha lempuk durian di Kabupaten Bengkalis. Kesimpulan penelitian ini adalah sebagai berikut:

1. Produksi adalah sebagai kegiatan mengenai penciptaan dan penambahan atau utilitas terhadap suatu barang dan jasa. Untuk menghasilkan produksi yang baik maka perlu memperhatikan adalah faktor-faktor produksi yang pada umumnya digunakan adalah tenaga kerja, tanah, dan modal. Kelangkaan pada suatu faktor produksi biasanya akan menyebabkan kenaikan harga faktor produksi tersebut.

2. Produksi lempuk durian mengalami penurunan diakibatkan karena bahan baku utama yaitu durian sangat sulit didapatkan dan harus mencari pemasok durian dari luar Bengkalis yang menyebabkan para usaha dagang tidak berani untuk memproduksi. Akan tetapi, bagi sebagian usaha dagang mereka tetap memproduksi lempuk durian dari luar Bengkalis sehingga produksi mereka tetap berjalan.

3. Menurut hasil penelitian, usaha lempuk durian yang ada di Kabupaten Bengkalis memberikan kontribusi dalam menciptakan lapangan pekerjaan, mengurangi pengangguran dan menambah pendapatan. Hal tersebut dapat meningkatkan perekonomian bagi keluarga masyarakat lemah.

Berdasarkan kesimpulan hasil penelitian, ada beberapa saran untuk perkembagan dan kemajuan produksi usaha lempuk durian di Kabupaten Bengkalis:

1. Agar produksi lempuk durian dapat memenuhi target yang telah ditetapkan perusahaan, maka pihak usaha dagang perlu membuat perencanaan bahan baku yang lebih baik serta membuat target yang jelas terhadap pemenuhan kebutuhan bahan baku dari pihak lain, sehingga tidak terjadi kekurangan bahan baku.

2. Dalam menyusun rencana produksi hendaknya diperhitungkan kondisi lahan perkebunan yang ada dan kondisi mesin dan peralatan produksi yang dimiliki. Sehingga penetapan rencana produksi tidak terlalu tinggi yang sulit untuk 
dicapai.

3. Para Usaha Dagang hendaknya lebih memperhatikan kondisi dan jumlah tenaga kerja yang terlibat langsung dalam proses produksi lempuk durian sehingga tidak terjadi kekurangan tenaga kerja untuk mencapai target produksi yang hendak dicapai para usaha dagang.

4. Dalam penggunaan tenaga kerja sebaiknya para pemilik usaha dagang memperhatikan skill dan kemampuan tenaga kerja agar tenaga kerja yang digunakan dalam proses produksi lempuk durian benar-benar bisa memenuhi kualifikasi yang dibutuhkan perusahaan untuk mencapai target produksi yang dibutuhkan.

\section{DAFTAR PUSTAKA}

Agung, I Gusti Ngurah, Pasay, N. Haidy A. \& Sugiharso. 2008. Teori Ekonomi Mikro: Suatu Analisis Produksi Terapan. Jakarta: PT. Raja Grafindo Persada.

Ahyari, Agus. 2002. Manajemen Produksi Perencanaan Sistem Produksi, Edisi Empat. Yogyakarta: BPFE.

Al-Arif, M. Nur Rianto. 2010. Teori Mikro Ekonomi. Jakarta: Kencana Group.

Antonio, Muhammad Syafi'i. 2001. Bank Syariah Dari Teori Ke Praktik. Jakarta: Gema Insani.

Ari, Sudarman. 2004. Teori Ekonomi Mikro, Edisi 4. Yogyakarta: BPFE UGM.

Assauri, Sofjan. 2004. Manajemen Produksi Dan Operasi. Jakarta: Lembaga Penerbit Fakultas Ekonomi Universitas Indonesia.

Badroen, Faisal dkk. 2006. Etika Bisnis Dalam Islam. Jakarta: Kencana Group.

Departemen Agama. 1997. Al-Qur'an dan Terjemahannya. Jakarta: PT. Bumi Restu.

Departemen Agama RI. 2009. Al-Quran dan Terjemahannya. Bandung: PT Sygma Examedia Arkanleema.

Departemen Pendidikan Nasional. 2002. Kamus Besar Bahasa Indonesia Cetakan II. Jakarta: Balai Pustaka.

Djuwini, Dimyudin. 2008. Pengantar Fiqh Muamalah. Yogyakarta: Pustaka Pelajar.

Effendi, Rustam. 2003. Produksi Dalam Islam. Jakarta: Gema Insani.

Harahap, Sofyan Syafri. 2006. Analisis Kritis atas Laporan Keuangan, Edisi I Jakarta.

Hasan, Iqbal. 2006. Analisis Data Penelitian Dengan Statistik. Jakarta: Bumi Aksara.

Karim, Adimarwan. 2007. Ekonomi Mikro Islami. Jakarta: PT Raja Grafindo Persada.

Machfoedz, Mahmud. 2007. Pengantar Pemasaran Modern. Yogyakarta: Andi Offset.

Muhammad. 2005. Metodologi Penelitian Ekonomi: Teori dan Aplikasi, Cetakan III. Jakarta: PT. Raja Grafindo Persada.

Milles, Mattew B. dan Hubermen, A. Machael. 1992. Analisa Data Kualitatif, Buku Tentang Sumber Metode-Metode Baru. Jakarta: UI Press. 
Nasution, Mustafa Edwin dkk. 2007. Pengenalan Ekslusif Ekonomi Islam. Jakarta: Kencana.

Pangestu, Subagyo. 2000. Riset Operasi. Edisi Pertama. Yogyakarta: BPFE.

Pangestu, Subagio. 2000a. Manajemen Operasi, Yogyakarta: BPFE.

Prabowo, Bagya Agung. 2012. Aspek Hukum Pembiayaan pada Perbankan Syariah. Yogyakarta: UII Press.

Pusat Pengkajian dan Pengembangan Ekonomi Islam. 2009. Ekonomi Islam. Jakarta: Rajawali Pers.

Rahman, Arif. 2010. Strategi Dahsyat Marketing Mix for Small Business: Cara Jitu Merontokkan Pesaing. Jakarta: TransMedia Pustaka.

Reksohadiprojo, Sukanto. 2000. Dasar-Dasar Manajemen. Yogyakarta: BPFE.

Saleh. 2003. Industri Kecil Sebuah Tinjauan dan Perbandingan. Jakarta: LP3ES.

Suharsimi, Arikunto. 2006. Prosedur Penelitian Suatu Pendekatan Praktik. Jakarta: Rineka Cipta.

Sukirno, Sadono. 2006. Mikro Ekonomi Teori Pengantar. Jakarta: PT. Raja Grafindo Persada.

Sule, Erni Trisnawati dan Saefullah, Kurniawan. 2008. Pengantar Manajemen. Jakarta: Persada.

Swastha, Basu. 2002. Azaz- azas Marketing. Yogyakarta: Liberty.

Syafril. 2004. Ekonomi. Jakarta: Bumi Aksara.

Yazid, Zulian. 2005. Manajemen Kualitas Produk dan Jasa. Edisi Pertama, Cetakan Keempat. Yogyakarta: Ekonisia. 